\title{
Czech Puppet Theatre in Global Contexts: Roots, Theories and Encounters
}

\section{Trans-national Origins and the Move to Seclusion}

For over a century, the Czech lands, with Prague at their heart, have been internationally considered the capital of the world of puppet theatre. ${ }^{1}$ That was no coincidence. It was in Prague that UNIMA (l'UNion Internationale de la MArionette, or the International Puppetry Association) was founded in May 1929, during an international puppetry exhibition and congress held by the Masaryk Educational Institute (Masarykưv lidovýchovný ústav). There were other associations participating in the venture - Nos marionettes (France, established by Gaston Cony), [le] Théâtre de marionettes (Germany, set up in 1921), and The Puppet and Model Theatre Guild (UK, set up in 1925). The Czech hosting institution had subsumed an earlier national puppetry initiative established as early as 1911, the Czech Union of Puppet Theatre's Friends (Českýsvaz prátel loutkového divadla), and was thus effectively the oldest association of puppet theatre in the world. The key personality behind many of these activities was the historian, collector and enthusiast Jindřich Veselý (1885-1939), who had also established the first puppetry journal in the world The Puppeteer (Loutkár)), in 1912 (the first three issues, 1912-1914, having been called, more nationalistically, The Czech Puppeteer (Českýloutkár̆)). It was not surprising that the presidency of the new international union UNIMA was offered to Veselý, with the central office in Prague and Loutkár as its official journal (1929-1930).

Thanks to UNIMA, as well as to the activities of individual puppetry artists, scenographers, collectors, curators, historians and theorists, the greatness of Czech puppet

1 This article is published as part of the research grant project Czech Structuralist Thought on Theatre: context and potency, held by the Faculty of Arts, Masaryk University, Brno, 2011-2015; funded by the Czech Grant Agency, grant no. GA409/11/1082. 
theatre has lasted and even grown - many of these key figures are either written about in the essays in this volume, or they have authored key historical texts themselves. As of 1 January 2015, the Czech Republic has recognised at state level the performative tradition of marionette theatre as: 'an intangible cultural asset of traditional folk culture' (see the official site of the Czech Ministry of Culture: http://www.mkcr.cz and http:// bit.ly/1JLULMz). The application to have traditional Czech puppets recognised as an Intangible Cultural Heritage of Humanity on the UNESCO list is imminent - a move that will achieve for Czech puppetry a status equal with that attained by Sicilian puppet theatre (opera dei pupi) in 2001 (see http://www.unesco.org/culture/ich/RL/00011), Indonesian Wayang Golèk (three-dimensional wooden puppets) and Wayang Kulit (twodimensional shadow puppets), Japanese Ningyo Johruri Bunraku in 2003 (http://www. unesco.org/culture/ich/RL/00063), and Chinese shadow puppetry in 2011 (http://www. unesco.org/culture/ich/RL/00421).

The Czech tradition of puppet theatre - perhaps just like any other theatre tradition is not a result of home-grown arts, developed in a sealed environment, however. Theatre traditions are inspired, created, developed and recognised through cultural encounters - from the initial enchantment with the exotic and the shock at the 'Other', through vicarious re-imaginations, to formal perfections and refined stylisation. Czech puppet theatre accordingly comprises numerous and varied trans-historical and trans-national influences: from pan-European medieval biblical visions, showing the 'creation and chaos of the world', through the folk tradition of mechanical Christmas cribs, in spectacular experimental automata that developed the earlier tradition of mobile icons and 'mechanical saints' (as Brooke Conti called it), ${ }^{2}$ via the Newtonian divine mechanism of the World. Such spectacular initiatives included early modern proto-commercial enterprises of travelling puppeteers originating in Italy, France and elsewhere in Europe, and also the imitation of Baroque court culture (i.e. operas, masques and other elite entertainments) in the cheaper, more portable and thus more 'popular' medium of puppet theatre. The formal perfection and refined stylisation of the Czech tradition was consummated during the course of the nineteenth century - still in part an international phenomenon that took its place as one part of a wider Central European theatre culture of itinerant puppet performers. Despite this rich and diverse cultural backdrop, however, Czech travelling marionettists were also isolated; they were secluded from the rest of the world by legal restrictions and impositions placed on them; they were not given licences to perform in the cosmopolitan hubs of their own country (i.e. regional capitals and spa resorts - places that were generally Germanspeaking and frequented by the wider international community, by entrepreneurs, as well as by more high status performers). Czech marionettists thus performed in the countryside, in villages and small towns, catering mostly for the lower (and thus Czech-speaking) social strata of the Habsburg Empire. Accordingly, they slowly acquired a status as 'folk'

2 BROOKE, Conti. The Mechanical Saint: Early Modern Devotion and the Language of Automation. In (HYMAN 2011: 95-107). 
performers and took on a crucial cultural role in the birth of Czech national patriotism (which in real terms meant the development of a Czech counter-culture within a German state). This creeping social and linguistic seclusion and its concomitant turn inwards towards one language and a folk audience conserved the Czech variety of puppet art and developed it into an autochthonous tradition - one that transformed its many, multifarious inspirations into a culturally unique form that has its parallels in other cultures, yet has most inimitably created its own very singular poetics.

\section{II 'His Motion is no Italian Motion but Made in London': The Early Modern Roots of Czech Puppet Theatre. ${ }^{3}$}

\section{II.i The Crux}

The roots of Czech puppet theatre are profound and convoluted. The tradition was continuous since time immemorial - however uncritical, yet appropriate term that is - until the twentieth century. However, before the nineteenth century, it is difficult to trace any continuities with the help of modern concepts - such as those of national traditions, institutions and enterprises, or of cultural heritage, whether material or immaterial. In this section of the introduction to our volume, I would like to present a set of propositions and methodological issues that not only complicate the actual study of early modern roots of - let us call it more appropriately - central European puppet theatre, but also to aim at drawing a complex image of the tradition and its possible predecessors. ${ }^{4}$

Traditionally, theatre historiography is founded on writing narratives of continuity and development built on historical facts and evidence. These continuities are based on individual artists and creators, on institutions (companies, aristocratic or communal ceremonies, on physical buildings), on material artefacts (such as scenography, stage technology, visual documents) or on genres. The latter is perhaps most complicated in that genres are immaterial and highly mobile and flexible. They are also most susceptible to cultural change and developments of taste: with every tipping point in society, genre - as a sociological phenomenon - may be abandoned, reworked, parodied, profaned as well as dignified. The problem arises when none of these continuities are sufficiently available to the study of history - which is the case of puppet theatre.

3 Section II of this introduction has been sole-authored by Pavel Drábek.

4 I would like to thank several friends and colleagues for their help with this section of the introduction, namely Melinda Gough (McMaster University) for drawing my attention to Eva Griffith's book; Nora Probst (Theaterwissenschaftliche Sammlung Köln and University of Cologne) for providing me with Carl Niessen's book; Tiffany Stern (University of Oxford) for her puppet materials and discussions; Peter W. Marx (University of Cologne) for his pilgrimage and methodological polemics; and Tomáš Kačer (Masaryk University) for Bartošs book. Finally, but crucially, my thanks go to the Theater Without Borders research collective, who heard an early version of this paper at our conference at the University of Oxford (23-26 June 2014; co-organised by Christian M. Billing, Clare McManus and Robert Henke). 
There are studies dedicated to individual marionettists and puppet masters: these are theatre encyclopaedias such as Alena Jakubcová and Matthias J. Pernerstorfer's edition of the multi-authored lexicon Theatre in Bohemia, Moravia and Silesia - from the Beginnings to the Late Eighteenth Century (Theater in Böhmen, Mähren und Schlesien. Von den Anfängen bis zum Ausgang des 18. Jahrhunderts, 2014) that contains a number of entries dedicated to early modern puppet performers and marionettists, outlining personal continuities where these are known - often passed down through the family. There are also monographs dedicated to individual puppet theatre dynasties, such as Alice Dubskás The Travels of the Puppeteers Brát and Pratte Through Europe in the Eighteenth and Nineteenth Centuries (DUBSKÁ 2012); necessarily, these works focus on the more recent centuries. The earlier ones are treated for instance by Bärbel Rudin in her article: 'The Travelling People: Puppet Theatre as Profession: News and Commentaries from the Seventeenth and Eighteenth Centuries' (Das fahrende Volk. Puppenspiel als Metier: Nachrichten und Kommentare aus dem 17. und 18. Jahrhundert, RUDIN 1976), in which she traces not only the personal continuities but also the replicated practices and repertoire iterations throughout early modernity: Rudin also points out, very importantly, that puppet theatre was not an exclusive art in which troupes would necessarily specialise; artists offered a range of skills - from acrobatics, music, tricks, circus-like shows, through puppet theatre to live actors' theatre, presenting perhaps the most complex image of the arts to date. This is a modern study that develops earlier attempts at a historically accurate and critical history of early modern puppet theatre, such as Jaroslav Bartošs 1960 mimeographed Seventeenth-and Eighteenth-Century Puppeteers in Bohemia, Moravia and Silesia (Loutkáři sedmnáctého a osmnáctého věku v Čechách, na Moravě a ve Slezsku, BARTOŠ 1960). Rudin's focus is on repertoire items, also developed in her 1980 article on the transmutations of 'shoemaker and St Dorothea plays' (RUDIN 1980). In the introduction to our current volume, I will develop this methodology of early modern transnational influences using the concepts of theatergram (CLUBB 1989; HENKE and NICHOLSON 2008), as well as the dramaturgical concept of double etymology, which I first outlined in my essay 'English Comedy and Central European Marionette Theatre’ (DRÁBEK 2014). Here, as there, I will trace further points of contact and similarities between early modern English drama and the standard repertoire of Central European puppetry.

Publications that aim at a more comprehensive treatment of puppet theatre as an institution are, for instance, Henryk Jurkowski's compendious monograph A History of European Puppetry: From Its Origin to the End of the Nineteenth Century (JURKOWSKI 1996), or Alice Dubskás history of the last two centuries of Czech puppetry (DUBSKÁ 2004), which in turn critically revises the earlier comprehensive studies such as Jan Malík's serially published monograph of 1964-1970 (MALÍK 1964-1970). Studies dedicated to material artefacts mapped against the historical circumstances form the bulk of puppet theatre histories. Again, these are necessarily limited to the more recent two centuries from which material artefacts survive - marionettes themselves, trick and variety 
puppets, curtains and wings, theatres and recorded dramatic texts for puppets. These are, for instance, Milan Knížák’s 2006 encyclopaedia of puppet theatre scenographers (KNÍŽÁK 2006), and especially the seminal works of Jaroslav Blecha, Pavel Jirásek and Marie Jirásková: The Czech Puppet (Česká loutka, BLECHA and JIRÁSEK 2008) and the Jiráseks' The Puppet and the Modern (in Czech as JIRÁSKOVÁ and JIRÁSEK 2011; in English as JIRÁSKOVÁ and JIRÁSEK 2014).

In writing histories that span the early period - roughly pre-1800 - and the last two centuries, there is a historiographical, methodological crux. While there are numerous records of early modern puppeteers documenting the popularity and wide dissemination of the art form through (and beyond) Europe, no plausible narrative of continuity with more recent times has been written - and perhaps it even cannot be provided, given the evasive and even elastic nature of the practices. Many professional folk marionettists claimed ancient roots and century-long origins of their art; they also claimed that their marionettes were centuries old. At the same time, this self-aggrandisement and propping up of one's own name and renown belongs to the style of travelling performers, marketplace entrepreneurs and traders with fiction. On the one hand, their puppet theatre as immaterial, 'intangible cultural heritage', as UNESCO defines it (see http:// www.unesco.org, namely http://bit.ly/1Hlirkv), is inherited from generation to generation as a cultural asset; on the other, its actual material artefacts are susceptible to natural attrition (puppets need to be mended and even replaced on a regular basis); it is also subject to dynastic developments (when an heir is handed down the art but needs to provide their own artefacts) and equally to the changing tastes of audiences - and these are not only incessant, but also the audience's satisfaction is the ultimate measure of the enterprise's success. Marie Jirásková and Pavel Jirásek, in their essay on trick puppets and variety shows for this volume, infer that these developments of taste: the trick puppet of the lady transforming into a hot-air balloon, or the puppet gymnasts costumed as members of the Sokol movement testify to the fact that tricks - some of them perhaps of ancient origin - were updated to match the novelties of each receiving society and its interests. At the same time, does this awareness authorise us, for instance, to assume that a similar trick puppet had existed and been used in puppet shows before la montgolfière of the late eighteenth century? Even more: if there hadn't been such a trick puppet, are we authorised to make assumptions about the very existence of trick puppets, as such, before this earliest surviving artefact?

\section{II.ii 'The Last Syllable of Recorded Time': Names and Words}

Theatre histories work with a series of assumptions and predilections - one of the assumptions being artistic unity and consistency, and one of the widespread predilections being what I would call affective probabilities (by which I mean hypotheses governed by subjective notions of likelihoods; cf. TALEB 2007 or ZAJONC 1984). For instance, 
most (if not all) studies of early modern theatre somehow inherently, if tacitly, assume that professional theatre performances were controlled by a single artistic mind; this is apparent in Shakespearean studies as well as in studies of Neoclassical French theatre - while practices that were often not only contemporaneous but often also more popular are bypassed as inferior, or of less historical, critical and theoretical interest. By the same token, theatre activities are generally seen as self-standing while historical evidence shows that theatre entrepreneurs were simultaneously active in trades and other professions. ${ }^{5}$ That has until recently certainly been the case of puppet theatre, which has inherited a pejorative reputation dispensing with it as un-artistic, merely popular (and often low-brow) entertainment. This went hand in hand with the predilection for artistic unity - a quasi-divine act of creation that demiurgically transformed the stage into a vision of perfection, a kind of epiphany of genius. It is unnecessary to elaborate on the epistemological anachronism of such assumptions: early modern theatre practice was - more often than not - a collection of various arts in composite programmes that presented to their audiences a variety of entertainments (see also KATRITZKY 2008: 36 and GRANT 2007; for the continuation in early twentieth-century practice, see Marie Jirásková and Pavel Jirásek's essay and Martin Bernátek's essay in this volume). On the early modern London stage and beyond - often symptomatic as a case of early demiurgical unities - the practices were not different, despite the majority of histories written on it. These were not only such projects as the medley of triumphs, the co-authored Four Plays in One (ca.1608-ca.1613) by John Fletcher and his atelier but also the quodlibets of the time, known as 'what-you-wills', which presented a collection of recycled popular scenes. That was not only the case of Francis Kirkman's The Wits, or Sport upon Sport, a collection of stage drolls published and reprinted in several parts (1662-1673), but also of the earlier plays, such as John Marston's What You Will (1601) with its most telling induction, and also, in a way, of William Shakespeare's Twelfth Night, or What You Will (ca.1601) and his reverie in the style of John Lyly: As You Like It (ca.1598).

To make assumptions about performances whose texts were never printed - and there were perhaps about 3,000 unpublished plays between 1576-1642 - would be highly speculative; however, travelling practices outside London suggest that individual shows were interlaced with songs, music, acrobatics and other entertainments including puppetry - hidden under the all-encompassing name of player (see McMILLIN and MacLEAN 1998). Abroad, in German-speaking Europe, early modern taxonomies were muddled by the names of Instrumentist or Springer (jumpers) or Spieler (players) (see also SPOHR 2009). Theatre historiography, as a result of its prejudice against puppet theatre, has often unwittingly obliterated the range of art forms that are subsumed under the early modern names of theatre professions. Among the lasting prejudices, which have their firm roots in early modern Christian Europe, is the association of puppets with idolatry and with

5 See especially the research of M. A. Katritzky (KATRITZKY 2007, 2008 and 2012), Natasha Korda (KORDA 2011), or Robert Henke (HENKE 2008). For Shakespeare as 'Johannes Factotum' see (HONIGMANN 1986). 
a primitive perspective of the Catholic creed; perhaps rightly; thus, and perhaps by shorthand, other actors were also often associated with unreformed Christianity.

\section{II.iii 'No Italian Motion but Made in London': Theatre Vogues and Folklore}

In early modern English documents, puppets were often referred to as motions - rather than puppets, because the word puppet had negative connotations through false etymological similarity with popery (BUTTERWORTH 2005: 126-7), hence idolatry, and equally because the other name, mamets was corruption of Mahomet - thereby fuelling further religious prejudices against the art form. The word motion avoided these connotations, and (as a result) it is often impossible to tell in historical documents if the evidence refers to puppets or mechanical theatre because just one term: motion referred to both. The religious dimensions of puppet theatre were further enhanced by the deeprooted idolatry or worship of images as devotional objects of pre-reformation Christianity. Henryk Jurkowski, in the above-mentioned history, refers to the Synod of Tiers of 1310, which encouraged pastors 'to use pictorial presentation for evangelising and the propagation of religious knowledge' (JURKOWSKI 2005: 63). As I have observed, 'In the high Middle Ages, movable objects, effigies and quasi-puppets, now known as statues, were used to perform the mysteries of Easter, Ascension, and Christmas' (DRÁBEK 2014: 179). It was the Easter play of the death and resurrection of Christ in particular that was performed by travelling puppet players in continental Europe until the end of the sixteenth century, or by local communities - and it is perhaps one of the rare literal continuities that can be traced to the twentieth century. Jaroslav Blecha documents exactly such a genealogy in his essay on the Flachs family in this volume. ${ }^{6}$ The traditional folk marionettist Jan Flachs Jr. (1855-ca.1940) received a licence to perform:

Physical exercise and gymnastic productions, rope-dancing, merry-go-rounds, puppet theatre, passion plays with the accompaniment of music with the help of son Rudolf Flachs. (Performance licence given by the county council in in Vsetín on 13 January 1937, valid till 31 December 1939; emphasis mine).

The link between puppet theatre and religion was profound; many early modern motions and more recent plays had biblical themes, or dealt with hagiographic legends. Travelling performers in early modern England were often connected with Catholicism (BEIER 1985: 97). Marionettists and presenters of mechanical motions would be

6 In personal communication, Blecha observed that this continuity may be mistaken; he is unaware that other marionettists than the Flachs would be performing passion plays. Blecha is of the opinion that the reference to 'passion plays with the accompaniment of music' in the Flachs' licence refers to the Jenovéfa play. Should that be so, another continuity could be established as the Jenovéfa originated in Jesuit Nicolaus Avancini's (1611-1686) play Genovefa Palatina, which in turn reworks medieval hagiographies and virtue exempla (see POLEHLA 2011: 35-9). 
liable to such allegations, as testified by several incidents documented by the Records of Early English Drama project (REED). One such instance took place at Coventry in 1599, where the motions where banned as popish idolatry. Another instance took place in Beaminster in 1623, where the puppet show called The Chaos of the World by William Sands resulted in a riot.

As Wendy Beth Hyman has observed:

what was suppressed in Reformation churches reappeared on stage: from the mock puppet show of Jonson's Bartholomew Fair to the moving statue scene of The Winter's Tale, from the fantastical engineering of the Jacobean and Caroline court masque to even the boys' theaters, automata gave audiences the chance to witness, if only in the theater, what their parents had once witnessed in church. And although stage magic was never more than a semi-legitimate art form, its puppet theaters, painted statues, and even child actors all crossed the nature/art divide in sometimes religiously charged ways: displacing interiority with iconicity, investing matter with transcendent qualities. (HYMAN 2011: 10-1)

Much remains to be clarified regarding the nature of early modern puppet shows. While it is known that the presence of puppeteers - also called 'presenters of motions' or even 'players', to add to the confusion - was frequent and more or less constant throughout the early modern period, such performances could encompass anything from simple trick puppets, mechanical tableaux (e.g. the well-known mechanical Christmas cribs; see NIESSEN 1982: 16 or KAFKA 2009) and automata, through unspecified elaborate devices such as the popular seventeenth-century show The Creation [or The Chaos] of the World, which is mocked in Ben Jonson's Bartholomew Fair, to narrative plays. This may have been the case of The Witches of Lancashire, performed at the King's Arms at Oxford on July 10,1635 - and one can only speculate if this was a puppet version of Richard Brome and Thomas Heywood's The Late Lancashire Witches of the previous year, or a motion exploiting the popularity of the London play and capitalising on the contemporary fascination with flying, or transvection as it was known then (see BOOTH 2007).

It is not incidental that these early seventeenth-century activities of puppet performers coincide with the encounters between English players and Italian performers. These connections, however, need to be seen in a broader geographical perspective - though we can establish a direct personal link, in which English, German and Italian itinerants served as media of transnational theatre exchanges. While theatre plays may be resistant to travelling because of language barriers, with puppets and automata in general it is near impossible to set any national boundaries.

The English comedian Robert Browne (1563-ca.1622) and his family are a prime example. Robert Browne senior was active in London theatres, as a member first of The Lord Admiral's Men, and later as a sharer of the Globe (after William Sly in 1608) as well as 
a member and tutor of the Children of The Queen's Revels (see BRAND and RUDIN 2011 and Otto G. Schindler and Bärbel Rudin's entry 'Robert Browne' in JAKUBCOVÁ and PERNERSTORFER 2014: 75-7). From the early 1590s, Browne had an important presence on the continent: his troupe was seen by Fynes Morrison performing 'pieces and patches of English plays' in Frankfurt in 1592. In the same year, he played with Thomas Sackville in Wolfenbüttel for Heinrich Julius of Braunschweig. Separate from Sackville he toured German cities between the years 1599 to 1601, and 1602 to 1603. In 1603, he performed at the Habsburg Imperial Court (then in Regensburg). It was probably Browne who had played for the Emperor and his Council in Prague in October 1602. Some two years later Robert Browne teamed up with John Green's troupe for further tours of France, Bohemia, and Poland. Robert Browne senior returned to England relatively often for brief periods of time - for commercial and entrepreneurial purposes, as has been observed. His daughter Jane lived in Germany, married to the actor Robert Reynolds, the famous Pickelhering, also a member and later leader of John Green's company. It was Johann Schilling (or Hans Schilling), born in Freiberg in Saxony who became the leader of the troupe and inheritor of their repertoire in 1628 and led the troupe until the early 1650s.

Through their contacts with the Habsburg Imperial Court, the troupe would regularly encounter Italian actors. In 1627 this company under Reynolds' leadership performed at the double coronation of Eleonora Gonzaga and Ferdinand III in Prague, side by side with Giovanni Battista Andreini's Compagnia dei Gelosi and another Italian troupe of the Commedia dell'Arte: Pier Maria Cechini's Comici Accesi. These three companies' paths very likely crossed on other occasions too - possibly in Austria (in Tyrol, the rivalry between the Accesi and the Gelosi broke out) or later, in 1614, where they performed in southern Bohemia - namely in Budweis (České Budějovice) and in Krumau (Český Krumlov) for Emperor Matthias.

While it is difficult to trace any certain Italian traits in the performances of the English actors in German-speaking Europe - perhaps apart from the superficial observation that their genre was referred to as the engelische comoedie, mirroring the commedia all'italiana and their sung comedies (Singspiele, jigs) perhaps imitative of the Italian madrigal comedy (see BOLTE 1893) - there seem to have been other spheres in which Italian theatre practice influenced English performers.

Robert Browne senior's second wife Cecily (Cisley, Cicely) was born Sands. Her brother was William Sands, a joiner from Preston, who received a licence from Sir Henry Herbert, Master of the Revels, in 1623:

to William Sands and others to show 'the Chaos of the World' (quoted in BUTTERWORTH 2005: 134),

which he had been working on and performing for seventeen years. In 1626 and later, the show was repeatedly performed in Oxford and mentioned in the diary of the theatre enthusiast of Queen's College, Thomas Crosfield. 
June Schlueter points out that William Sands':

two sons, John and William, were also puppeteers: with their father, they were the subject of a 1630 complaint about 'certain blasphemous shewes and sights which they exercise by way of poppett playinge' (HAYS, et al. 121-2). In his will of 11 September 1638, William Sandes bequeaths 'my Shewe called the Chaos, the Wagon, the Stage, \& all the Joyners tooles \& other ymplementes \& appurtenances to the said Shewe belonging to my sonne John Sandes' (George 87). (SCHLUETER 2014: 618)

The son of Robert Browne senior, a brother of Jane Reynolds and a nephew of William Sands, Robert Browne junior (1595-ca.1642) was also a player, and unlike his father and sister he was active in England. Close to his death in 1642, he is referred to as 'puppie player'.

M. A. Katritzky claims that 'Any connections [between the continental Robert Browne and] the provincial puppet troupe led by Robert Browne, George Hall and Richard Jones, remain speculative' (KATRITZKY 2005: 135, note 13). However, she does not seem to take into account the link between Cisley Sands and William Sands. In her recent book, Eva Griffith elaborates on the connection between the Browne dynasty in England and on the Continent:

Moreover, Browne, [Jane Reynolds'] father, had married Cicely Sands, who is likely to have been the sister-in-law of Christopher Beeston through his marriage to Jane Sands. This familial relationship of the Beestons, the Continental Brown and Reynolds makes sense in terms of the records we have of both Jane Beeston and the Reynolds family's many English indictments for non-attendance at church. On 1 January 1616, a Robert Reynolds along with Jane, his wife, appear in Middlesex sessions records with an Elizabeth Reynolds, Jane Beeston née Sands (wife of Christopher) and others to do with their theatrical community and they do so again in March records of the following year, 1617 - on both occasions, for recusancy. (GRIFFITH 2013: 184)

On the continent, these puppet masters' relatives had joined with the Freyberger Springer (the jumper of Freiburg) Johann Schilling (elsewhere referred to as the jumper of Erfurt or of Cologne). In the repertoire performed in Dresden later, Schilling had among other alluring titles - a puppet play entitled Comödia von der Erschaffung der Welt (a Comedy of the Creation of the World). June Schlueter also suggests that perhaps this puppet show could be the same as that licensed by Sir Henry Herbert in 1623 as the 'Shewe called the Chaos'. This seems to be a likely instance of a theatre artefact exported from England to Germany.

George Speaight, the author of English Puppet Theatre, thinks that the English practice differed substantially from the continental. He observes that the marionette type of puppets (i.e. puppets suspended on a wire and controlled from above with a series 
of strings) was not the practice in England, unlike continental Europe, and he assumes that the prevalent form were glove puppets (SPEAIGHT 1990: 65) - productions of Ben Jonson's Bartholomew Fair have mostly followed this conclusion. However, the reality is that the continental standard - at least in northern, central and eastern Europe - were puppets on a stick and controlled from below - as the early evidence suggests (compare with the mikrlata type of puppets in Blecha's essay in this volume, and also the puppet types documents in Niessen's book on puppet theatre in Rheinland; NIESSEN 1928: 97, 112-3). That was the case with the Italian puppet master Antonio Benozzi, who was active in Central Europe in the years 1689 to 1696. It follows that the late seventeenth-century Benozzi was still observing the standard tradition. At the same time, the tradition was well established (despite a shortage of extant evidence). The fact that there were aristocratic puppet theatres built to the purpose testifies to the popularity of as well as to the respect for the genre. One such instance is Herzog Georg Wilhelm of Celle, who had a puppet theatre built in the style of the Commedia dell'Arte by the Italian painter Arighini.

The consequence for the export and import of theatre influences in the Sands-BrowneReynolds family is that even the puppet traditions seem to have been - and possibly were - identical. A possible import into England could be the Italian influence. While the English comedy seems to have been competing with the Commedia all'Italiana in the lands of Habsburg influence, back in England, English players would often tour with an Italian motion - a common enough artefact of the 1630s and 1640 s.

However, on 9 October 1639, a certain George Hall and a Robert Browne (probably the brother-in-law of the Pickelhering Robert Reynolds who had performed opposite the Gelosi and the Accesi) were not given license to perform their 'Italian motion' in Norwich. The account says:

Robert Browne and George Hall Did this Day exhibit a lycence from Sir Henry Herbert master of the Revelles to shewe an Italian motion but because he sayth his motion is noe Italian motion but made in London this Court thinkes fitt not to suffer them to shewe. (Norwich REED 1984: 232)

Philip Butterworth muses over the possible reasons - whether 'an Italian motion is one that comes from Italy? Or is the response at Norwich a parochial one concerned with local reasons for turning down Brown and Hall?' (BUTTERWORTH 2005: 138). Neither of Butterworth's questions seems appropriate: as for the former, we have seen that 'an Italian motion' is likely to be one in the Italian style, perhaps featuring character types of the Italian commedia or presenting puppets of the Italian fashion. As for Butterworth's latter question, an 'Italian motion' was certainly no novelty in Norwich: one 'Iohn Stone' had been denied a licence to show his 'Italian Motion' in Norwich on 21 December 1633 (Norwich REED 1984: 213), whereas on 23 December 1635, Thomas Gaskell was successful, as the records show: 
Thomas Gaskell to sett forth an Italian motion, he hath leaue so to doe till Tuesday night next \& no longer (Norwich REED 1984: 222)

What is worth observing is that both of these visits (of 1633 and 1635) came to Norwich at Christmas (Advent) time, so the Italian motion could have been a version of the Christmas Crib. Perhaps with the increasingly exacerbated religious situation of the Caroline era, in 1639, Robert Browne and George Hall with their (religiously dubious?) Italian motion were refused licence when it turned out that 'Italian' did not mean 'made in Italy' but connotated other Italian legacies. While there were several other instances in which an Italian motion was licensed even to an English puppet performer, this instance is a piece of evidence of Italian influence smuggled by the entrepreneurial Browne family, trafficking in theatre styles.

\section{Il.iv Early Modern Curiosity Shows and Revues}

Of course this piece has often been produced here; but how we are going to show and present it today, can hardly ever have previously come to light...

[Es ist freylich dieses Stuck schon offt hier produciret worden / aber wie wir heute solches bestellen / und vorstellen werden / schwerlich zum Vorschein kommen...]

a poster for Faustus play with a Hans-Wurst, Prague 1728.

(reproduced in BARTOŠ 1960: annexe V)

Later documents of puppet performances in the seventeenth and eighteenth centuries suggest not only their great popularity but also the great variety of shows and techniques that were offered by travelling puppeteers. Besides the well-documented merging of the English and Italian traditions (see also HAVLÍČKOVÁ and NEUHUBER 2014 and my review of it in this volume), in the crossovers between the English clown Pickelhering and the Italianate (or Frenchified) Harlequin and the puppet 'Policinelle', numerous extant posters, licences and other documents testify to the type of shows that travelling puppeteers gave.

So in 1721, Johann Ernst Leinhaas (?), performing in the Manhart Palace in Celetná Street in Prague (today's seat of the Arts and Theatre Institute), promised:

the merry and curieus ropedancing [...] as well as a shadow play [...] on our little people or puppets that will make altogether merry dancing and plays on the Theatro [dass lustige und curieuse Sail-Tanzen [...] wie auch das Schatten-Spiel[...] auff unsere Männlein / oder Poppen / welche auff dem Theatro allerhand lustige Täntz und Spiel machen werden.] (reproduced in BARTOŠ 1960: annexe IV) 
In September 1717, Johann Franz Deppe, performing in Prague, advertised a lengthy list of his performative offers that he made 'with the permission of the high authorities' (Mit Bewilligung einer Hohen Obrigkeit). It is worth citing his poster in full:

Even here shall the newly arrived Compagnie present to its curieuse lovers of the German theatre play with sight-worthy comedies, tragedies, pastorals and various ballets and dances on a rare Theatro by illuminated lights and sweet music with such sumptuous figures (i.e. puppets) that none such can be found in all of Germany, at which the Austrian peasant Hans Wurst will, with his jesting, sufficiently entertain the curieuse lovers, and will begin here today on Wednesday 29 September for the first time, today's comedy being entitled:

Count Torello of Pavia, Unluckily by the Turks Imprisoned, or Hans Wurst's Double Wedding. After the ending of this admirable main action, for further entertainment, a Maid and a Scarmutz [Scaramouche] will make several high leaps.

N.B. In conclusion will always be a merry after-comedy with live personas at which a merry Harlequin will show himself.

[Wird die alhier Neu-ankommende Compagnie denen curieusen Liebhaberen der Teutschen Schau-Spiele auffwarten / mit sehens-würdigen Comödien / Tragedien / Schäfereyen / und allerhand Balletten und Tänzen auff einem raren Theatro / bey angezündeten Lichtern / und lieblicher Music / mit solchen kostbaren Figuren / dessen gleichen in ganz Teutschland nicht zu finden / worbey sich ein Oesterreiche Bauer Hans Wurst mit seiner Lustbarkeit / die curieusen Liebhaber genugsam vergnügen wird / und wird heute Mittwochs den 29 September zum Erstenmahl angefangen werden / die heuntige Comödi wird betittlt:

Der von den Türcken unglückselig gefangene Fürst Torello von Pavia.

oder Hans Wursts doppelte Hochzeit.

Nach Endigung dieser admirabeln Haubt-Action wird zu mehreren Vergnügung / eine Jungfer und ein Scarmutz etliche Lufft-Spring machen.

NB. Zum Beschluss wird allezeit eine lustige Nach-Comödie mit lebendigen Persohnen / worbey sich ein lustiger Harlequin wird sehen lassen.]

(reproduced in BARTOŠ 1960: annexe IV).

Deppe's poster suggests that his performance is not only a mixture of Italian, French, German and Austrian influences (with a tiny taste of Turkish tribulation), but also early evidence of practices that were soon to be inherited by puppeteers performing in Czech (such as Jan Brát; see DUBSKÁ 2012) - as well as testimony of the quodlibet (or what-you-will) type of variety shows typical of early modern travelling performers and combining dances, acrobatics, puppet plays and live actors' theatre in one programme. Perhaps, the additional entertainment of the high leaps of a 'Maid' and a 'Scaramouche' could have been instances of acrobatic trick puppets. 
In other recorded instances and surviving posters, it becomes clear that additional numbers on offer in the period were puppet operas (or is that what Deppe means by plays with sweet music?), trained animals, or visual displays representing faraway cities or battles. The latter was not only the case of the Brát family (DUBSKÁ 2012), but also, in the previous century, the article of many travelling entertainers - such as, in Norwich, one 'Edward whitinge' who was allowed 'to shewe his Sight of Antwerpe' in 1630 , a 'William Gostlynge' who was 'to shewe the portraiture of the City of Ierusalem' in 1635, or 'Danyell Abbot' in 1638, who was much less specifically coming 'to shewe sightes' (Norwich REED 1984: 202, 219, 226). These are performative varieties associated with early modern puppet theatre that span the two eras.

The travelling performers appearing in Prague at the turn of the seventeenth and eighteenth centuries, such as Leinhaas or Deppe, were not distant either from the English comedians-cum-puppeteers of the earlier century, who performed in Prague too, nor from the later marionettists whose activities fall into the last two centuries and are documented by the conventional historiographical evidence. It is here - in the quodlibet puppetry shows of early modern central Europe - that the variety of transnational influences collides and transforms into the roots of the indelible heritage that has materialised into the unique phenomenon of Czech puppet theatre.

\section{The Czechoslovak State and Puppet Theatre during the Twentieth Century: a Curse and a Blessing}

Notwithstanding the vibrant early-historical genealogy articulated above, the Czech tradition of puppet theatre did not simply 'stagnate' as a result of its years within the unique purview of Czech travelling folk marionettists. In many ways, in fact, the folk marionettists of the late eighteenth and nineteenth centuries acted as custodians of a wide historical tradition that, although deeply imbued with Czech wood-sculptural, scenographic and dramaturgical particularities, was also a clear inheritor of Central and wider European traditions, techniques and customs. With the arrival of the twentieth century, traditional Czech puppet theatre was perceived by many as obsolete and anachronistic, which eventually led to the decline and disappearance of the live folk tradition - as several of the essays in this volume discuss in detail - however, the new, decidedly modern (and Modernist) initiatives that replaced the old art form did not eliminate puppetry. In a movement called the 'Puppetry Renaissance' (see essays by Bernátek, Jirásek, Lešková Dolenská and Malíková in this volume), a now uniquely Czech phenomenon was transformed as a function of the needs of modern Czech society; and the Czech cultural heritage contained in and represented by Czech puppetry (albeit acting as a theatrical repository for previously more widespread theatre forms) was given a new and equally unique life. Despite the ups and downs of the political, economic and cultural turmoil of the (sometimes terrifyingly) eventful twentieth century, Czech puppet theatre thus grew 
in importance and in its artistic achievements. This transformation took place, quite literally, in the hands of Modernist and Avant-garde theatre artists who were active from the 1920 s to 1940 s. Thanks to the care of the many puppet theatre companies and groups that emerged during these years (whether professional or amateur), as well as to the many innovative film makers and animation specialists who gave, in the well-recognised art-form of Czechoslovak animation, the old tradition a surprising and a rich new life: in the early experiments of Hermína Týrlová (1900-1993); the inventor of the prehistoric (Jurassic) world of animation Karel Zeman (1910-1989); the renowned visual artist Jiří Trnka (1912-1969); the prolific Břetislav Pojar (1923-2012); or the world-famous Jan Švankmajer (born 1934).

As several of the essays in this volume document, modern Czech puppet theatre has raised dozens of first-class scenographers and visual artists, and, in so doing, it has played a crucial role in building the equally renowned Czech school of scenography. One characteristic of this trend (i.e. the move towards serious consideration of the objects and inert paraphernalia of theatrical presentation, not just as a function of their materiality, but also in deeply philosophical terms, as elements of performance that act and inter-act with humans in ways that both lead to an acceptance of theatrical reality (verisimilitude) and also to the conscious problematisation of the artifice of theatre) has been that the Czech scenographic imaginary is one in which artists often have the express purpose of questioning normative assumptions about the ways in which humans interact with their world: Czech scenography has thus become a medium for challenging many existential commonplaces - and much of this can be linked to puppet practice and theory. One example of this interrelation is Prague School Structuralism, a movement that could only have been born into a cultural moment that was aware enough about the 'object'-ification of theatre and its necessary material realities to bother to take the time to deconstruct them to philosophical effect. One attempt at exactly this project is the essay by Otokar Zich, 'Puppet Theatre' (Loutkové divadlo, 1923), appearing for the first time in this volume.

Zich's essay is testimony to the fact that the 'Puppet Renaissance', and its later developments in Modernist and Avant-garde theatres, gave birth to another crucial and in many ways unique discipline: the theory of puppet theatre. Zich's essay is little known; but this work and this man are central to the development of Western theatre theory. A Professor of Aesthetics at Charles University (1924-1934), a theorist and an opera composer, Zich is widely recognised in Czech academia as the founder of modern theatre theory thanks in large part to his monumental Aesthetics of Dramatic Art (Estetika dramatického umění, 1931) - a book that has paradoxically not yet been published in English. ${ }^{7}$ Zich's book

$7 \quad$ Translation and publication of this volume is currently in hand, and constitutes part of the strategic plan of the research team of the Theatre Studies Department at Masaryk University, Brno (led by Assoc. Prof. David Drozd). The translation will be part-financed by the grant project: Czech Structuralist Thought on Theatre: Context and Potency, held by the Faculty of Arts, Masaryk University, Brno, 2011-2015; funded by the Czech Grant Agency, grant no. GA409/11/1082. 
gave a vital impulse to the newly established Prague Linguistic Circle (Pražský lingvistický kroužek, established in 1926, also known as the Prague School). The leading members of this body (themselves an international group) created a seminal corpus of criti$\mathrm{cal}$ and theoretical texts dealing with theatre Structuralism and semiotics - among them Jan Mukařovský (1891-1975), the Russian linguist Roman Jakobson (1896-1982), the ethnologist Peter (Pyotr) Bogatyrev (1893-1971), the leading Czech Avant-garde stage directors Jindřich Honzl (1894-1953) and Emil František Burian (1904-1959), and the younger generation of theorists, including Karel Brušák (1913-2004) and Jiří Veltruský (1919-1994). Such texts as Mukařovskýs 'An Attempt at a Structural Analysis of an Actor's Figure (Chaplin in City Lights)' (Chaplin ve Světlech velkoměsta. Pokus o strukturní rozbor hereckého zjevu, 1931), Jindřich Honzl's 'Dynamics of the Sign in the Theatre' (Pohyb divadelního znaku, 1940) or Jiří Veltruskýs 'Dramatic Text as a Component of Theatre' (Dramatický text jako součást divadla, 1941), have played a decisive role in subsequent theatre theory and the critical thinking of an entire discipline.

The same group of theorists published extensively on questions of puppet theatre and never truly separated the artistic realm of the puppet from that of the otherwise dominant type: live actors' theatre (see, for instance, Veltruskýs posthumous An Approach to the Semiotics of Theatre, 2012). It was most particularly Peter Bogatyrev whose ethnographic interest led him decisively towards a theory of puppet theatre. Bogatyrev theorised puppet theatre systematically - not only in the well-known seminal essay 'Theatre Signs' (Znaky divadelní, 1938; published in English with a somewhat misleading title 'Semiotics in the Folk Theatre'), but also in an essay 'A contribution to the study of theatrical signs' in his 1940 book Czech and Slovak Folk Theatre (Lidové divadlo české a slovenské), and in his 1946 reaction to Zich's 'Puppet Theatre'; such detailed theoretical thinking is also present in his works as early as the 1923 Russian-language essay 'Czech Puppet Theatre and Russian Folk Theatre' (Cheshskyi kukolnyi teatr i russkyi narodnyi teatr, in Sbornik po teoriyi poeticheskovo yazyka, 1923; published in English in TDR 43.3 (Fall 1999)). Finally, Bogatyrev revisited his 1937 essay towards the end of his life, in an essay entitled 'The Interconnection of Two Similar Semiotic Systems: The Puppet Theatre and the Theatre of Living Actors' (O vzaimosviazi dvukh blizkikh semioticheskikh sistem; published posthumously in 1973 in Trudy po znakovy sistemam 6; and in English in Semiotica 47 (1983): 47-68). It is of far-reaching significance that Bogatyrev's theories, as well as those of his Prague School colleagues, centred around Czech puppet theatre. The initial impulse for its theoretical reflection came from Otakar Zich (and from Bogatyrev's ethnographic study) and developed gradually into a canon of puppet theatre theory - as Frank Proschan's special issue of Semiotica 47: 1-4 (1983) shows, as well as Henryk Jurkowski's recently revised Aspects of Puppet Theatre (Palgrave Macmillan, 2014).

Ground-breaking theoretical achievements in theatre theory of this sort do not emerge from a vacuum; and the explosion of Avant-garde artistic practices that were re-defining what the words 'Czech' and 'Puppetry' meant when they were placed next to each other, was characteristic of the theatrical and theoretical synergy that pertained for most of the 
first half of the twentieth century. As has been mentioned above, for this explosion of creativity to have taken place in a Czech 'ark' of cultural preservation, that had somehow sustained, nurtured and developed pan-European traditions and practices ranging from the middle ages to modernity, meant that both Czech theorists and Czech practitioners were considering/experimenting with/deconstructing a full panoply of available forms and methods. To deploy a culinary metaphor: they were cooking with a full set of ingredients and potent spices. It is this extraordinary temporal, cultural and geographical coincidence (a coalescence, concurrence, a réduction à lessentiel in the Czech milieu) that forms the backdrop to each of the essays that follows in this volume. Whether describing the lead up to the 'Puppetry Renaissance', examining in detail its practitioners and products, considering its legacy, or expressing elegiac articulations of the now-pressing question: 'nevrospastos quo vadis?', the Czech context of our volume is key.

The vibrant elements of Czech puppet theatre in all their forms constitute a truly unique phenomenon in the world of theatre and performance. It is also true to say that the pan-European heritage that Czech puppetry preserves, maintains, calls on, develops and allows the Czech puppetry tradition once again to take on and speak with authority in truly global contexts.

\section{The Articles In This Volume}

Jaroslav Blecha's contribution deals with one of the major itinerant puppeteer families of the Czech lands, the Flachs. Probably originating in South Bohemia, this nineteenthand early twentieth-century dynastic family can be used, as Blecha deploys them, as a paragon case study of the scope, form, nature and artistic practices of the 'folk' traditionalists who kept the well-head open above the deep reserves of art and culture that lay below, in the historical past. Blecha's analysis includes an account of repertoire (with an investigation of its dramaturgical implications) as well as the forms of the puppets used and the traditions of carving in which they were placed. His detailed analysis also points to the cultural circumstances that surrounded both nineteenth- and twentieth-century practices by itinerant families, including their fall from fashion (for Avant-garde artistic reasons), during the 'Puppetry Renaissance' and, subsequently (for anti-capitalist ideological reasons), in the Czechoslovak Republic after the Communist takeover of 1948. Blecha's analysis combines first-rate historiographical and technological scrutiny with a deeply personal account of the lives of real human beings, and their fortunes in a changing world.

The next contribution, from Marie Jirásková and Pavel Jirásek, deals with the concept of 'Puppet Cabaret' during the first half of the twentieth century. This article expressively describes the many trick and transformation puppets of the previous travelling folk marionettists and how these were developed according to the Avant-garde tastes of the twentieth century. Moving outwards from a concept of 'variety' puppet theatre, 
the Jiráseks articulate a new epistemological paradigm for our understanding of puppet theatre. Their analysis (unsurprising for authors who are also major collectors of puppets and marionette ephemera) is on the materiality of early twentieth-century puppet objects. Their analysis deliberately objectifies their subject and, in opposition to the historic thrust of central European and Czech theatre studies (a tradition that has preoccupied itself with detailed linguistic, performative and staging analyses of the marionettists' texts or theatre practices), they offer instead a sophisticated account of what is not shared with the actors' theatre, what makes the genre unique: the puppets themselves. In a synthetic presentation of what they call 'the mystery of the revived matter - or: the visual dramaturgy of a form of theatre that is scenographic spectacle par excellence', the Jiráseks parade before their readers a puppet pageant, representative of 'a [Modernist, experimental] theatre whose technological finesse was often anxiously protected as the trade secrets of marionettist families and companies'.

Providing another epistemic shift in the analysis of early twentieth-century puppet performance, Martin Bernátek's essay turns to the cultural synergies that existed between puppet theatre during the period of the 'Puppetry Renaissance' and the cinema. Looking in detail at what can be learnt from the various ethnographical and technological exhibitions and events that took place in Czechoslovakia during the opening decades of the twentieth century (and their desire to create a new, technologically advanced, bold, proud Czech[o]Slovak nation), Bernátek maps onto puppet practice several of the shared characteristics that were coincident in the development of photography, cinematography and puppet theatre scenography. Behind these surface similarities, however, lies a much deeper history of the connection between national pride, technological invention and Modernist (even Futurist) ideologies; Bernátek's essay thus gives an account of the reasons why puppet theatre left the domain of the folkloric and infant-focussed world that it had inhabited for the last two centuries and began to work with many of the Avant-garde movements of the period (including collaborations with key Surrealists, Symbolists and so on). In this way, he charts a path that was shared by the developing cinema and puppet theatre: a journey to find new forms of entertainment that could depart from the Naturalism and Realism of the actors' theatre in the period. However, and crucially, he demonstrates the ways in which puppet theatre offered, and was deliberately developed as, a significant alternative to an increasingly verisimilitudinous cinema. As his quotation of, Bohumil Schweigstill demonstrates: 'Puppet theatre - 'plain [and] primitive' - combines the qualities of graphic instructiveness and of the beautiful word in an otherwise tedious skioptikon [with] the attractiveness of movement and liveness in an otherwise unwholesome and 'mute' biograph [i.e. cinema].' In a sophisticated inquiry, Bernátek's analysis offers new insights on the ways in which puppet theatre developed 'within a context of a conservative/modern binary of cultural emancipation'. What is interesting with the case of Modernist puppetry, is that it seems that its radical re-workings of the tools, stock and figures of the past could lead to an Avant-garde art- 
form that was, at that time, impossible in the world of cinema. Moreover, it was precisely through their self-distinguishing, and their desire to act as alternatives to actors' theatre and the early cinema, that Czech puppet practitioners established a form of performance that became unique in the world.

Pavel Jirásek's essay, which follows in the volume, deals with a single practitioner: Josef Skupa. Jirásek charts the career of this modernising artist, the inventor of Spejbl and Hurvínek, from his phenomenal successes in Prague, Pilsen and Paris in the late 1920 s to his death in 1956. In a detailed account of a rounded individual, drawn from a substantial amount of primary and secondary evidence, Jirásek considers Skupa holistically, giving attention to his many achievements in glove puppet design, puppet theatre design (architectural and technical), scenography, marionette design, acting and dramaturgy. In each element of the profession, Skupa is shown to have had not simply a high level of proficiency and artistic flair, but also a desire to reinvigorate, to modernise and to develop what was emerging as a truly unique Czech tradition. Combining analysis of Skupa's designs, the testimony of his peers and the subsequent academic accounts and analyses of his work, Jirásek in our volume presents one of the most direct and clearly articulated versions of this major figure that is available - and certainly in English.

The contribution of Kateřina Lešková Dolenská is a study of the dramaturgy of puppet theatre. Through an analysis that is both literary and historiographical, Lešková Dolenská maps out the repertoires of most of the major puppet companies operating in pre-national epochs, followed by Czechoslovakia, then the Czech Republic and Slovakia, during the twentieth and twenty-first centuries. Beginning with the travelling 'folk' marionettists, the essay outlines an epistemological crux in the post-Enlightenment separation of the concepts of 'education' and 'entertainment' in the theatre. The first section of the essay then presents a chronological analysis of puppet theatre repertoires, practitioners and practices, with a focus on the ways in which Czech puppet theatre retained traditional forms, and dramaturgical stock during the nineteenth century, followed by the ways in which, during the 'amateur' era, the dramaturgy and characterisation of key characters (such as Kašpárek) was changed, as a function of re-alignment with different (largely family) audiences. The essay includes interesting examples of puppet dramaturgy as a kind of early applied theatre (with plays such as Germ-boy (Bacilinek) being used in proto-public-health campaigns, and then moves through the 'Puppetry Renaissance' and subsequent full professionalisation of puppet theatre during the rest of the twentieth century - both pre- and post-Velvet Revolution (1989), together with its consequences. The conclusion of Lešková Dolenskás essay prefigures some of the questions that are taken up more fully by Nina Malíková later in the volume - when the latter author asks what is at stake, in developmental terms, in that fact that contemporary Czech puppet theatre seems to have fostered a 'lack of original works' - or, fallen back on a dramaturgical imaginary that is too reliant upon the comfortable stories of the past. Lešková Dolenskás claim - that '[current Czech puppet theatre] rarely deals with the contemporary 
world, it basically does not open new topical issues, it is not socially active, nor critical' is, or should be, a clarion call to puppeteers and academic authors alike, to question the normative ruts into which both theory and practice can sometimes fall.

Katarzyna Lech provides us with something entirely different. Her essay is based on ecocritical readings of several works by the Czech puppet practitioner, Jakub Krofta, in his Polish productions. Taking as a starting point the emergence in recent years of a persuasive movement in relation to animal rights and its interactions and engagements with the cultural domain, Lech looks first at the history of Czech puppetry practitioners in Poland, and then the role of marionette and mixed media actor and puppet theatre in ecopedagogy. With a particular emphasis on the strategies that can be deployed in a theatre of objects in relation to setting up and then critiquing relationships between humans and animals, Lech considers the nature of 'agency' as a concept in puppet theatre. Widening this topic out to embrace the agency of animals, and following applied theatre routes to a consideration of political processes and rights, Lech close-reads several important scenes from two Krofta plays: Daszeńka and Pacan in order to assess the ways in which a particularly Czech-inflected style of hybridised puppet performance (that draws attention both to puppet's operators and also to the differences between live actors and puppets) can be used to positive ecopedagogical effect. In particular, the ways in which such artistic practices can be traced back to the theatre-pedagogical imperatives of the Prague Academy of Performing Arts, School of Alternative and Puppet Theatre (Katedra alternativního a loutkového divadla) is presented.

A further essay that is based on close reading of performance comes in Georgia Chryssouli's article on the work of Czech stop-action animator, graphic artist, and Surrealist sculptor Jan Švankmajer. In an astute analysis of the films: The Last Trick of $\mathrm{Mr}$ Schwarzewald and Mr Edgar, Punch and Judy, Don Juan, Faust, Alice and Jabberwocky, Chryssouli examines the way in which Švankmajer uses tropes of hyper-violence and auto-destruction to comment, from a Surrealist-inspired perspective, on the awkward plight of humanity - particularly given that it seems to have invented for itself so many oppositional and confrontational structures (both social and psychological) within which to imprison its members. Chryssouli attends to the materiality of Švankmajer's films, demonstrates the invested weight of reification that is undertaken with man-made objects (often used to do hitherto unimagined things), and shows how this obtuse artificiality is frequently contrasted to the naïve innocence of the natural world - remember those guinea pigs and beetles that sometimes move so naturally amongst, across and around Švankmajer's stop-frame-animated machines and humans? Chryssouli focuses on the materiality of Švankmajer's oeuvre and its reliance on making familiar, everyday objects - those things so worn away with human touch that they have become artefactual witnesses to their interdependence with humans - strange enactors of unexpected rituals. Such moments of shock, Chryssouli argues, are deployed by the filmmaker to rupture the commonplace normatives that imprison us in hegemonically 
constructed prisons of the quotidian. In short, she shows how Švankmajer's evocation of the shocking and unexpected is entirely reliant on a form of object animation that is deeply rooted in Czech cultural traditions of Symbolism, Surrealism, Poetism and, most importantly, puppet performance.

In one last exercise in close reading, Dan North also considers Švankmajer alongside other Czech stop-motion animation film makers, Jiří Bárta and Jan Svěrák; but this time from the perspective of the object status of puppets and other toy-like objects in their cinema. North's emphasis is once again on the quotidian wear and tear that links objects (both loved and just necessary ones) to human contact. North conceives of the puppet as both an inanimate object and a profoundly moving (in both senses of the world) articulator of 'emotional investment and historical freight'; however, he chooses to linger on a concept that is often rejected in modern puppet theory: its connection to childhood. North's essay therefore provokes some very interesting questions, amongst them: why should a powerful cultural valence that is connected to childhood, to memory, to innocence and to pleasure be dismissed as infantile? Why should critical responses to art that focuses on the realm of the child be pejorative? How do puppets (and not just those with children's toy-like qualities, but all puppets) connect us both viscerally and emotionally to a forgotten past, a nostalgic, memorial essence after which we secretly hanker? To what effect can puppet practitioners, or animators in the mould of Švankmajer, Bárta or Svěrák deploy such a powerful connection - that reaches right to the roots and substance of any ontologically perceptive human subject? Richly researched in not just the history of Czech puppet theatre, but also in theories of human psychology, materiality and reification, North's essay maps out the ways in which objects are charged by their contact with the world, and become, in Švankmajer's words: 'susceptible under certain conditions of delivering up their contents and, on contact, of revealing associations of ideas and resemblances from our own unconscious impulses.'

The last academic essay in the volume is elegiac in its tone; in it, Nina Malíková charts out the landscape of contemporary puppet theatre in the Czech Republic, asking the potent question: 'Is Czech Puppet Theatre an Endangered Species?' Malíková notices a resurgence in academic interest in the historical roots of Czech puppetry - both in the eighteenth- and nineteenth-century folk traditions and in the experimental years of the early and mid-twentieth century. When interest turns to the past, it can often mean that the present is less inspiring, and Malíková questions the notion of 'tradition' in order to tease out the various strands of logic and history that allow people to talk of a specifically 'Czech' variant of marionette theatre. Sensing a hiatus in the shift from puppet theatre in which the primacy was always given to marionettes, to a new consideration of puppet theatre as just one constituent part of a wider genre of 'a theatre of objects' or an 'alternative and puppet' theatre (in which the status of the puppet, and the skills required in its manipulation, design and dramaturgy can sometimes seem to be just an additive afterthought), Malíková uses historical inquiry and provocative, rhetorical questioning 
to bring to the fore some of the dilemmas that need to be answered before a foundation can be established on which the future of Czech puppetry can be based. She asks: 'Is it possible that contemporary Czech puppet theatre stands with a self-authored theatrical 'decomposition', ahead of it as its inevitable path as a theatre form? Is it insufficient motivation that diverts students from this art form in its traditional varieties? Or does their vision of puppet theatre anticipate a new symbiosis of visual and theatrical forms for which we do not yet have a proper name? Is it possible that the crisis in puppet practice signifies the prototypic emergence of a new form of puppet theatre?' Withholding her prophetic voice, Malíková leaves her readers simply with the advice of the wise observer: "let us watch closely the development of contemporary puppet theatre, to ascertain whether it contains more alternatives, or whether it returns to tradition; and let us not try to enforce what any of us might individually or collectively think is its only true and orthodox form.

Our volume also contains two accounts of practitioners in action: Agnès Novak's (with Dušan Petráňs) account of Yorick's Marionette Theatre / Les Marionnettes de Yorick a Czech-inspired puppet theatre founded in the United States of America by Petrán in 1990 and running there until 2010, at which point (and after the arrival to the company of Agnès Novak), the company re-located to France. The narrative is a fascinating first-hand account of the ways in which a puppet theatre company evolves, develops and integrates itself both within a wider non-Czech host culture, but also with the resident diaspora for whom its 'Czech-ness' and its portable signifiers of Central European identity are a major attraction of the art-form. Equally interesting in the account, is the tale of the ways in which artistic success, and even sustainability, is intimately connected to the economic and political climate of performance cultures. In their account of the shifting landscape of North American art and politics, Novak and Petrán outline a sad decline in artistic openness and financial support for small and medium scale companies in the USA, subsequent to the economic crisis of 2007/8. Equally distressing is the evidence of a turn away from the experimental artistic spirit that characterised the funding of the United States National Endowment for the Arts from its inception in the mid 1960s until the middle of the 1980s - at which point a series of provocative artworks, dealing with taboo subjects, prompted the ire and censure of the religious and conservative right and a concomitant dip in its funding until the teen decades of the new millennium. Now located in France, Les Marionnettes de Yorick face a different set of financial and cultural challenges, but the company continues to make socially engaged work that connects with local audiences, and both charms and challenges audience assumptions in equal measure.

In another account of artistic and curatorial practice, Joseph Brandesky's descriptive piece outlines two interlinked projects that brought Czech puppets to Columbus, Ohio in 2013. Brandesky outlines the content and intentions of a major exhibition to display, contextualise and interpret over one hundred and forty objects and items in relation to Czech puppets, which was mounted for six months at the Columbus Museum of Art. In 
the same account, he also describes a collaborative project with the designer Petr Matásek, with whom Brandesky developed a postmodern theatre show that combined live actors and puppets: aPOEtheosis. With the benefit of the relatively long timeline that is required to develop an international exhibition at a fully functioning museum, Brandesky and his team simultaneously devised, designed, scripted and directed a stage production that could illustrate for American audiences contemporary Czech puppet and object-animation techniques and principles in a live theatrical context. Brandesky's richly illustrated essay is an account of both projects, and their reception.

The penultimate item in this special issue is documentary once again. It is Martina Pecková Černás compilation of Czech puppet exhibitions, performances, companies and events, which is linked to the database held at the Arts and Theatre institute in Prague (Institut umění - Divadelní ústav, Praha). The list is not only an excellent compendium of such proceedings in the Czech Republic and worldwide, it is also testament to the living art of Czech puppetry and its status as a historical tradition worthy of major study.

Lastly, this volume closes with a historical appendix: the first English language translation of the seminal essay by Otakar Zich that we have discussed in section III above.

It has been a pleasure to work with such skilled authors during the preparation of this volume. Ultimately, we hope that readers of this special issue will conclude with us that Czech puppet theatre is a tradition and a living art of immense importance to the cultural heritage of many given lands and moments of history. We therefore very much hope that readers both enjoy and benefit from the significant range of materials so adroitly presented here by thirteen different living authors, and one genius, sadly now dead for nearly one hundred years. We are certain that all readers of this volume will agree with us that it is certainly true to say that, in a Czech cultural context, each of the elements of puppet theatre as it is accounted for in the pages that follow is an extraordinarily beautiful, and a particularly rich thread, located within a stunning and fabulous artistic tapestry.

\section{Bibliography}

BARTOŠ, Jaroslav. 1960. Loutkáři sedmnáctého a osmnáctého věku v Čechách, na Moravě a ve Slezsku [Seventeenth- and Eighteenth-Century Puppeteers in Bohemia, Moravia and Silesia]. Praha: SPN, 1960.

BEIER, A. L. 1985. Masterless Men: The Vagrancy Problem in England 1560-1640. London: Routledge, 1985.

BLECHA, Jaroslav and Pavel JIRÁSEK. 2008. Česká loutka [The Czech Puppet]. Praha: Kant, 2008. 
BOLTE, Johannes. 1893. Die Singspiele der englischen Komödianten und ihrer Nachfolger in Deutschland, Holland und Skandinavien [Sung Plays of the English Comedians and their Followers in Germany, the Netherlands and Scandinavia, 1893]. Reprint. Nendeln: Kraus Reprint, 1977.

BOOTH, Roy. 2007. Witchcraft, Flight and the Early Modern English Stage. Early Modern Literary Studies 13.1 (May 2007) 3.1-37. Available at <http://purl.oclc.org/emls/13-1/bootwitc.htm>.

BRAND, Peter and Bärbel RUDIN. 2011. Der englische Komödiant Robert Browne (1563-ca.1621): Zur Etablierung des Berufstheaters auf dem Kontinent [The English Comedian Robert Browne (1563-ca.1621). On the Establishment of Professional Theatre on the Continent]. Daphnis 39 (2011): 1-134.

BUTTERWORTH, Philip. 2005. Magic on the Early Modern Stage. Cambridge: Cambridge University Press, 2005.

CLUBB, Louise George. 1989. Italian Drama in Shakespeare's Time. New Haven: Yale University Press, 1989.

DUBSKÁ, Alice. 2004. Dvě století českého loutkářství: vývojové proměny českého loutkového divadla od poloviny 18. století do roku 1945 [Two Centuries of Czech Puppetry. The Developments of Czech Puppet Theatre from the Middle of the Eighteenth Century to 1945]. Praha: NAMU, 2004.

DUBSKÁ, Alice. 2012. The Travels of the Puppeteers Brát and Pratte Through Europe in the Eighteenth and Nineteenth Centuries. Praha: NAMU, 2012.

DRÁBEK, Pavel. 2014. English Comedy and Central European Marionette Theatre. In Robert Henke and Eric Nicholson (eds.). Transnational Mobilities in Early Modern Theater. Farnham: Ashgate, 2014: 177-96.

GRANT, Teresa. 2007. Entertaining Animals. In Brigitte Resl and Linda Kalof, gen. ed. A Cultural History of Animals. Volume 3. The Renaissance (1400-1600), ed. Bruce Boehrer. Oxford: Berg Publishers, 2007: 95-118.

GRIFFITH, Eva. 2013. A Jacobean Company and its Playhouse: The Queen's Servants at the Red Bull Theatre (ca. 1605-1619). Cambridge: Cambridge University Press, 2013.

HAVLÍČKOVÁ, Margita and Christian NEUHUBER (eds.). Johann Georg Gettner und dar barocke Theater zwischen Nikolsburg und Krumau [J. G. Gettner and the Baroque Theatre between Mikulov and Český Krumlov]. Brno: Masaryk University, 2014.

HENKE, Robert. 2008. Border-Crossing in the Commedia dell'Arte. In Robert HENKE and Eric Nicholson (eds.). Transnational Exchange in Early Modern Theater. Aldershot and Burlington: Ashgate, 2008: 19-34.

HENKE, Robert and Eric NICHOLSON. 2008. Introduction. In id. Transnational Exchange in Early Modern Theater. Aldershot and Burlington: Ashgate, 2008: 2-13.

HONIGMANN, E. A. J. 1986. Shakespeare and His Contemporaries: Essays in Comparison. Manchester: Manchester University Press, 1986.

HYMAN, Wendy Beth (ed.). 2011. The Automaton in English Renaissance Literature. Farnham: Ashgate, 2011. JAKUBCOVÁ, Alena and Matthias J. PERNERSTORFER (eds.). 2014. Theater in Böhmen, Mähren und Schlesien. Von den Anfängen bis zum Ausgang des 18. Jahrhunderts. Ein Lexicon [Theatre in Bohemia, Moravia and Silesia. From the Beginnings to the Late $18^{\text {th }}$ Century. A Lexicon]. Prague/Vienna: Institut umění - Divadelní ústav/Verlag der Österreichischen Akademie der Wissenschaften, 2014. 
JIRÁSKOVÁ, Marie and Pavel JIRÁSEK. 2011. Loutka a moderna [The Puppet and the Modern]. Praha: JAMU, Arbor Vitae, 2011.

JIRÁSKOVÁ, Marie and Pavel JIRÁSEK. 2014. The Puppet and the Modern. Transl. by Magdalena and Lawrence Wells. Praha: JAMU, Arbor Vitae, 2014.

JURKOWSKI, Henryk. 1996. A History of European Puppetry: From Its Origin to the End of the Nineteenth Century. Vol. 1. Edited by Penny Francis. Lewiston: Edwin Mellen Press, 1996.

KAFKA, Luboš. 2009. Betlemáři: kapitoly z historie a současnosti tvorby betlémů [Crib Makers: chapters from the history and the present of the making of Christmas Cribs]. Praha: Etnologický ústav AV ČR, 2009.

KATRITZKY, M. A. 2005. Pickelhering and Hamlet in Dutch Art: The English Comedians of Robert Browne, John Green, and Robert Reynolds. In Ton Hoenselaars and Holger Klein (eds.). Shakespeare and the Low Countries (= Shakespeare Yearbook 15). Lewiston: Edwin Mellen Press, 2005: 113-40.

KATRITZKY, M. A. 2007. Women, Medicine and Theatre 1500-1750: Literary Mountebanks and Performing Quacks. Aldershot: Ashgate, 2007.

KATRITZKY, M. A. 2008. English Troupes in Early Modern Germany: The Women. In Robert HENKE and Eric Nicholson (eds.). Transnational Exchange in Early Modern Theater. Aldershot and Burlington: Ashgate, 2008: 35-46.

KATRITZKY, M. A. 2012. Healing, Performance and Ceremony in the Writings of Three Early Modern Physicians: Hippolytus Guarinonius and the Brothers Felix and Thomas Platter. Farnham: Ashgate, 2012.

KNÍŽÁK, Milan. 2006. Encyklopedie výtvarníků loutkového divadla v českých zemích a na Slovensku od vystopovatelné minulosti do roku 1950 [An Encyclopaedia of the Visual Artists of the Puppet Theatre in the Czech Lands and in Slovakia from the Traceable Past to 1950]. Hradec Králové: Nucleus, 2006.

KORDA, Natasha. 2011. Labors Lost: Women's Work and the Early Modern English Stage. Philadelphia: University of Pennsylvania Press, 2011.

MALÍK, Jan. 1964-1970. Z letopisů dřevěné thálie [From the Chronicles of the Wooden Thalia]. Československýloutkáŕ [The Czechoslovak Puppeteer] XIV-XX (1964-1970).

McMILlin, Scott and Sally-Beth MacLEAN. 1998. The Queen's Men and their Plays. Cambridge: Cambridge University Press, 1998.

NIESSEN, Karl. 1928. Das Rheinische Puppenspiel. Ein theatergeschichtlicher Beitrag zur Volkskunde [The Rheinland Puppet Theatre. A Theatre Studies Contribution to Ethnography]. Bonn: Fritz Klopp Verlag, 1928.

Norwich REED. 1984. Norwich 1540-1642. Ed. David Galloway. Toronto: University of Toronto Press, 1984.

POLEHLA, Petr. 2011. Ctnosti a neřesti ve vybraných jezuitských (alegorických) hrách [Virtues and Vices in Selected Jesuit (Allegorical) Plays]. In Petr Polehla and Jan Hojda (eds.). Náboženské divadlo v raném novověku [Early Modern Religious Theatre]. Ústí nad Orlicí: Oftis, 2011: 32-42.

RUDIN, Bärbel. 1976. Das fahrende Volk. Puppenspiel als Metier: Nachrichten und Kommentare aus dem 17. und 18. Jahrhundert [The Travelling People. Puppet Theatre as Profession: News and Commentaries from the $17^{\text {th }}$ and $18^{\text {th }}$ Centuries]. Kölner Geschichtsjournal 1 (1976): 2-11. 
Czech Puppet Theatre in Global Contexts: Roots, Theories and Encounters

RUDIN, Bärbel. 1980. Fräulein Dorothea und der Blaue Montag [Virgin Dorothea and the Artisans' Holiday]. In A. J. Bisanz and Raymond Trousson (eds.). Elemente der Literatur: Beiträge zur Stoff-, Motiv- und Themenforschung [Elements of Literature: Papers on Research into Topics, Motives and Themes]. Vol. 1. Stuttgart: Alfred Kröner, 1980: 95-113.

SCHLUETER, June. 2014. No Puppets Dallying: Green's 1626 Production of Hamlet. Shakespeare Bulletin 32: 4 (Winter 2014): 613-28.

SPEAIGHT, George. 1990. The History of the English Puppet Theatre (1955). Second edition. London: Robert Hale, 1990.

SPOHR, Arne. 2009. 'How chances it they travel?' Englische Musiker in Dänemark und Norddeutschland 1579-1630. Wiesbaden: Harrassowitz Verlag, 2009.

TALEB, Nassim Nicholas. 2007. The Black Swan: The Impact of the Highly Improbable [2007]. London: Penguin Books, 2008.

ZAJONC, Robert B. 1984. On the Primacy of Affect. American Psychologist 39.2 (1984): 117-23. 


\section{Summary}

This article is both an introduction to this volume as well as to the rich and enchanting world of Czech puppet theatre, with its unique combination of transnational and geographically and cultural distinctive features. Pavel Drábek's essay, incorporated in this introduction, revisits the early modern roots of Czech puppet theatre, suggesting the possible missing links between the early practices, as documented in the travelling performers' tradition, and the tradition of the marionettists of the last two centuries. The introduction traces the developments of the Czech puppet theatre into the twentieth century and its impact on cinema as well as its key role in the shaping of modern theatre theory under the aegis of the Prague School.

\section{Keywords}

Czech puppet theatre, theatre history, UNIMA, early modern theatre, English travelling actors, quodlibet, variety show, motion, Robert Browne, Czech animation, Prague School, theatre theory

DOI: $10.5817 /$ TY2015-2-1

Christian M. Billing (c.m.billing@hull.ac.uk) is Senior Lecturer in Drama and Theatre Practice at the University of Hull, UK. He studied Drama, Theatre Studies and Greek Civilisation at the Universities of Kent, London, Leeds and Warwick; and first joined the permanent academic staff of the School of Drama, Music and Screen at the University of Hull in 2001 - after eleven years working professionally in film and theatre, and teaching dramatic literature and theatre practice at various universities in the United Kingdom and the United States of America. He is author of Masculinity, Corporality and the English Stage 1580-1635 (Ashgate, 2008) and editor of a Special Issue of Shakespeare Bulletin: Rehearsing Shakespeare: Alternative Strategies in Process and Performance (Vol. 30 No. 4, Johns Hopkins University Press, 2012). For Theatralia, this will be his second special issue, having previously co-edited with Pavel Drábek Czech Stage Art and Stage Design (special issue of Theatralia 14.1 (2011)). He is author of numerous book chapters and journal articles, particularly in the journals Shakespeare, Shakespeare Quarterly and New Theatre Quarterly, and he also publishes elsewhere in relation to the theory and practice of scenography; transnational and intercultural theatre and performance; current professional rehearsal and performance practices for historically-distanced playtexts; and gender studies - particularly in relation to early modern English and ancient Athenian drama and society.

Pavel Drábek (p.drabek@hull.ac.uk) is Professor of Drama and Performance at the University of Hull, UK. His interests range from early modern drama and theatre in Europe, through drama translation, music theatre to theatre theory. He has published on translations of Shakespeare (České pokusy o Shakespeara (Czech Attempts at Shakespeare), 2012), on John Fletcher (Fletcherian Dramatic Achievement: The Mature Plays of John Fletcher, 2010), on seventeenth-century English comedy in Germany, on early modern puppet theatre, and on theatre Structuralism (collaborating with the StruG Project, Masaryk University). He is an opera librettist (mostly for composer Ondřej Kyas), playwright and translator. He is the co-founder of the Ensemble Opera Diversa (www. operadiversa.cz) and was its Artistic Director for over a decade. With Christian Billing, he co-edited Czech Stage Art and Stage Design (special issue of Theatralia 14.1 (2011)). 
